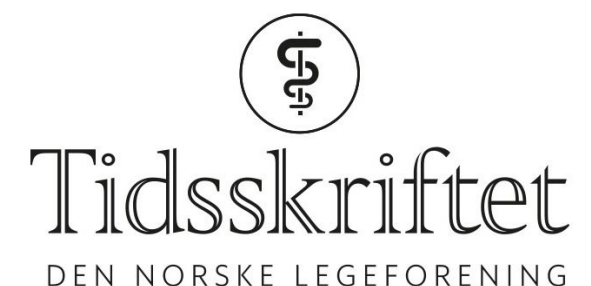

DEN NORSKE LEGEFORENING

\title{
Kjell Holten
}

MINNEORD

AMUND GULSVIK

FRODE GALLEFOSS

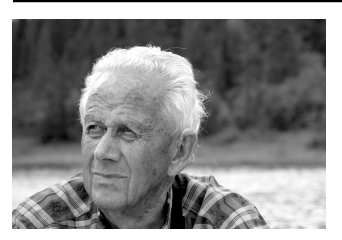

Overlege Holten døde 7. april 2018, en måned etter 95-årsdagen. Han var født på Sortland i Vesterålen. Ved Universitetet i Oslo tok han bifag i matematikk og grunnutdanningen i medisin. Han ble cand.med. i 1953, spesialist i lungesykdommer i 196o og i indremedisin i 1964.

Kjell Holten var en av de siste lungespesialistene i Norge som hadde meget stor erfaring i diagnostikk og behandling av tuberkulosepasienter. Han ervervet seg slik erfaring som kandidat, assistentlege og reservelege ved diagnosestasjonen og tuberkuloseavdelingen ved Kirkenes sykehus i 1954-57. Senere hadde han utdanningsstillinger ved sykehusene i Porsgrunn, Elverum og Bergen.

Han var initiativtager til og pådriver for etablering av moderne lungemedisin i Norge. Fra 1966 til 1976 var han spesiallege med ansvar for avansert respirasjonsfysiologi, senere overlege og i tre år også administrerende overlege ved Lungeavdelingen, Nordland sentralsykehus, Bodø. Fra 1976 til 1992 var han overlege ved Lungeavdelingen ved Vest-Agder sentralsykehus i Kristiansand, der han med sin generelle fagkunnskap og forskningsinnsats bidro til etablering av en fremragende avdeling for lungesyke på Sørlandet.

Kjell Holten var formann i Norsk forening for lungemedisin fra 1978 til 1982 og en av initiativtagerne til foreningens forskningsråd i 1982. Han samlet og digitaliserte foreningens arkiv for perioden 1919-98 og var æresmedlem i foreningen i mer enn 30 år.

Overlege Holten hadde en betydelig vitenskapelig produksjon, til tross for at han aldri hadde noen formell ansettelse eller noen veileder fra akademisk lungemedisinsk fagmiljø. Han var på mange måter selvlært, med en sjeldent kritisk evne til å tilegne seg ny kunnskap. Han stilte relevante og praktiske forskningsspørsmål, planla og gjennomførte forskningsprosjekter og fikk publisert funnene i internasjonale tidsskrifter med fagfellevurdering. Studiene inkluderte både diagnostiske prosedyrer, bruk av nye luftveisutvidende legemidler ved astma og kols, årsakssammenhenger mellom miljø og lungesykdom og effekt av trening ved alvorlig lungesykdom.

Holtens største fortjeneste var imidlertid hans interesse for og evne til å stimulere unge 
leger til å erverve seg mer kunnskap om lungesykdommer. Han var teknisk-matematisk begavet og kunne gi en forenklet pedagogisk fremstilling av de vanskeligste temaer. Han var ungdommelig nysgjerrig på fagets utvikling, opptatt av moderne vitenskapsfilosofi og usedvanlig kyndig innen informasjons- og kommunikasjonsteknologi for sin alder.

Han hadde store evner og skapte bedre helse for mange lungesyke både nord og sør i landet. Han var en fremtidsrettet sjef og veileder for mange unge lungeleger, men meget beskjeden på egne vegne. Han var mild av vesen, med en befriende og velutviklet humoristisk sans. Kjell Holten har nytt stor respekt i det lungemedisinske miljøet i Norge og vil få et meget godt ettermæle.

På vegne av det lungemedisinske fagmiljøet

Publisert: 8. mai 2018. Tidsskr Nor Legeforen. DOI:10.4045/tidsskr.18.0336

(C) Tidsskrift for Den norske legeforening 2020. Lastet ned fra tidsskriftet.no 